\title{
KEEFEKTIFAN MODEL PEMBELAJARAN KOOPERATIF TIPE STAD DAN TGT DENGAN PENDEKATAN KONTEKSTUAL DALAM PEMBELAJARAN MATEMATIKA TERHADAP KEMAMPUAN KOGNITIF, DAN SOSIAL SISWA
}

\author{
Rostien Puput Anggoro \\ Program Studi Pendidikan Matematika, FKIP UAD, Yogyakarta \\ Email: anggoro_puput@yahoo.com
}

\begin{abstract}
ABSTRAK
Penelitian ini bertujuan untuk: 1) Mendeskripsikan keefektifan model kooperatif tipe STAD dan TGT dengan pendekatan kontekstual dalam pembelajaran matematika, 2) Membandingkan keefektifan antara model pembelajaran kooperatif tipe STAD dan tipe TGT dengan pendekatan kontekstual dengan pembelajaran konvensional, dan 3) Membandingkan keefektifan antara model pembelajaran kooperatif tipe STAD dan TGT dengan pendekatan kontekstual dalam pembelajaran matematika, ditinjau dari kemampuan kognitif, dan sosial siswa. Desain penelitian yang digunakan adalah penelitian eksperimen semu dengan rancangan pretestposttest non-equivalent group design. Penelitian ini menggunakan dua kelas eksperimen dan satu kelas kontrol. Instrumen penelitian yang digunakan meliputi tes kemampuan kognitif matematika, dan angket kemampuan sosial siswa. Hasil penelitian menunjukkan bahwa: 1) pembelajaran kooperatif tipe STAD dan TGT dengan pendekatan kontekstual efektif pada kemampuan kognitif dan kemampuan sosial siswa, sedangkan pembelajaran konvensional tidak efektif pada kemampuan kognitif dan kemampuan sosial siswa, 2) Terdapat perbedaan keefektifan antara pembelajaran kooperatif tipe STAD dan TGT dengan pendekatan kontekstual dengan pembelajaran konvensional, serta tidak terdapat perbedaan keefektifan antara pembelajaran kooperatif tipe STAD dan pembelajaran kooperatif tipe $T G T$, ditinjau dari kemampuan kognitif, dan sosial siswa, dan 3) pembelajaran kooperatif tipe $S T A D$ dan pembelajaran kooperatif tipe $T G T$ lebih efektif dari pada pembelajaran konvensional, ditinjau dari kemampuan kognitif, dan sosial siswa.
\end{abstract}

Kata Kunci: Pembelajaran kooperatif tipe $S T A D$, Pembelajaran kooperatif tipe $T G T$, pembelajaran konvensional, kemampuan kognitif, dan kemampuan sosial.

\begin{abstract}
This research is aimed to: 1 ) describe the effectiveness of cooperative learning model of STAD and TGT type using the contextual approach in the mathematics learning, 2) comparing the effectiveness of cooperative learning model of STAD and TGT types using the contextual approach and conventional learning, 3) comparing the effectiveness of cooperative learning model of STAD and TGT types using the contextual approach in the mathematics learning in relation to cognitive competence and social competence student. This research is a quasi experiment research. The design of the research used is quasi-experiments with nonequivalent (pre-test and post-test) group design. This research used two experiment classes and one control class. Research instrument used cognitive competence test mathematic and social competence questionnaire. The results of the research are as follows. 1) The cooperative learning model of STAD and TGT types using the contextual approach is effective to cognitive competence and social competence student while conventinal learning not effective to cognitive competence and social competence student. 2) There is difference between the effective of cooperative learning model of STAD and TGT types using the contextual approach whit conventional learning, and not difference between the effective of cooperative learning model of STAD and TGT types using the contextual approach to he cooperative learning model of TAI type to cognitive competence and social competence student.
\end{abstract}


And 3) cooperative learning model of STAD and TGT types more effective of the conventional learning to cognitive competence and social competence student.

Keywords: STAD Cooperative Learning Model, TGTCooperative Learning Model, Conventional Learning, Cognitive Competence, and Sicial Competence.

\section{Pendahuluan}

Pembelajaran matematika di Indonesia hingga saat ini masih mengalami permasalahan yang belum mampu diselesaikan dengan baik. Permasalahan tersebut adalah masih kurangnya kemampuan kognitif siswa dalam mata pelajaran matematika. Hal ini ditunjukkan dengan masih rendahnya prestasi belajar siswa pada mata pelajaran matematika. Beberapa faktor penyebabnya antara lain banyak siswa masih beranggapan bahwa matematika merupakan mata pelajaran yang sulit dan membingungkan.

Permasalahan lain yang ada yaitu masih rendahnya kemampuan siswa dalam bersosialisasi dengan lingkungan sekitarnya, dalam hal ini teman, guru, dan warga sekolah yang lain. Siswa lebih cenderung bersifat individualis dan tidak peduli terhadap teman yang lain ketika pembelajaran berlangsung. Hal ini menyebabkan adanya kesenjangan antara siswa yang memiliki kemampuan baik dengan siswa yang kemampuannya kurang baik. Kerjasama siswa dalam menyelesaikan tugas atau masalah pun masih kurang. Interaksi dengan guru dalam pembelajaran masih belum optimal. Siswa sering merasa takut atau malu untuk bertanya mengenai materi yang disampaikan guru atau mengungkapkan suatu pendapat.

Untuk mengatasi permasalahan yang terjadi, dibutuhkan suatu pembelajaran matematika yang menyenangkan dan menarik, sehingga pelajaran matematika lebih mudah dipahami. Pembelajaran matematika juga sebaiknya mendukung siswa untuk berinteraksi dengan siswa yang lain untuk meningkatkan kemampuannya dalam bersosialisasi dengan orang lain. Dengan demikian diharapkan pembelajaran akan membentuk siswa yang memiliki kecerdasan intelektual sekaligus kecerdasan emosi secara seimbang.

Pembelajaran dengan model kooperatif (Cooperative Learning) dapat menjadi salah satu solusi untuk mengatasi permasalahan tersebut. Hal ini dikarenakan model pembelajaran kooperatif mengutamakan kerja sama dalam menyelesaikan permasalahan untuk menerapkan pengetahuan dan keterampilan dalam rangka mencapai tujuan pembelajaran. Dalam proses pembelajaran dengan model pembelajaran kooperatif, siswa didorong untuk bekerja sama pada suatu tugas bersama dan mereka harus 
mengkoordinasikan usahanya untuk menyelesaikan tugas yang diberikan guru. Tujuan model pembelajaran kooperatif adalah hasil belajar akademik siswa meningkat dan siswa dapat menerima berbagai keragaman dari temannya, serta pengembangan keterampilan sosial.

STAD dan TGT merupakan dua di antara beberapa tipe pembelajaran kooperatif. Prosedur penggunaan tipe $S T A D$ dan $T G T$ ini memiliki kemiripan. Satu-satunya perbedaan antara keduanya adalah STAD menggunakan kuis-kuis individual pada tiap akhir pembelajaran, sedangkan TGT menggunakan gamegame akademik. Gagasan utama dari STAD dan TGT adalah untuk memotivasi siswa supaya dapat saling mendukung dan membantu satu sama lain dalam menguasai kemampuan yang diajarkan guru. Jika para siswa ingin agar timnya mendapatkan penghargaan tim, mereka harus membantu teman satu timnya untuk mempelajari materinya. Mereka harus mendukung teman satu timnya untuk dapat melakukan yang terbaik, menunjukkan norma bahwa belajar itu penting, berharga, dan menyenangkan (Slavin, 2005: 6). Keadaan yang seperti ini akan meningkatkan kemampuan siswa untuk bersosialisasi dengan teman dan juga guru.

Selain model pembelajaran, solusi penyampaian materi juga dapat menggunakan pendekatan kontekstual dalam pembelajaran matematika. Pada dasarnya pembelajaran matematika dengan pendekatan kontekstual mengacu pada konstuktivisme. Belajar menurut konstruktivisme adalah siswa sendiri yang harus aktif menemukan dan mentransfer atau membangun pengetahuan yang akan menjadi miliknya.

Masalah dalam penelitian ini adalah: 1). Bagaimana keefektifan pembelajaran matematika dengan model kooperatif tipe $S T A D$ dan tipe $T G T$ dengan pendekatan kontekstual serta pembelajaran konvensional terhadap kemampuan kognitif, dan sosial siswa? 2). Manakah yang lebih efektif antara model pembelajaran kooperatif tipe STAD dan TGT dengan pendekatan kontekstual dengan pembelajaran konvensional ditinjau dari kemampuan kognitif, dan sosial siswa? 3). Manakah yang lebih efektif antara model pembelajaran kooperatif tipe STAD dan tipe $T G T$ dengan pendekatan kontekstual ditinjau dari kemampuan kognitif, dan sosial siswa pada pembelajaran matematika?

Tujuan penelitian ini adalah untuk mengetahui: 1). Mendeskripsikan keefektifan model pembelajaran kooperatif tipe $S T A D, T G T$ dengan pendekatan kontekstual dan konvensional ditinjau dari kemampuan kognitif, dan sosial siswa pada pembelajaran matematika. 2). Membandingkan 
keefektifan antara model pembelajaran kooperatif tipe $S T A D$ dan tipe $T G T$ dengan pendekatan kontekstual dengan pembelajaran konvensional ditinjau dari kemampuan kognitif, dan sosial siswa pada pembelajaran matematika. 3). Membandingkan keefektifan antara model pembelajaran kooperatif tipe $S T A D$ dan tipe $T G T$ dengan pendekatan kontekstual ditinjau dari kemampuan kognitif, dan sosial siswa pada pembelajaran matematika.

\section{Landasan Teori}

Menurut Arends \& Kilcher (2010: 306), Pembelajaran kooperatif adalah model pembelajaran atau strategi yang dicirikan oleh tugas kelompok, tujuan, dan struktur penghargaan, dan membutuhkan siswa untuk secara aktif terlibat dalam diskusi, debat, latihan, dan kerja sama tim. STAD merupakan salah satu metode pembelajaran kooperatif yang paling sederhana, dan merupakan model yang baik untuk permulaan bagi para guru yang baru menggunakan pendekatan kooperatif.

Menurut Borich (2000: 388), dalam Student Team-Achievement Division (STAD), guru menetapkan siswa dalam tim yang terdiri dari empat sampai lima orang anggota. Komposisi setiap tim dalam kelas harus heterogen yang terdiri dari (laki-laki/perempuan, prestasi tinngi/prestasi rendah, dan lain-lain).

$S T A D$ terdiri dari lima komponen utama, yaitu: 1). Presentasi kelas,
Presentasi yang dilakukan haruslah berfokus pada unit $S T A D$. Dengan cara ini, para siswa akan menyadari bahwa mereka harus benar-benar memberi perhatian penuh selama presentasi kelas karena dengan demikian akan sangat membantu merela mengerjakan kuis-kuis. 2). Tim, terdiri dari empat atau lima siswa yang mewakili seluruh bagian dari kelas dalam hal kinerja akademik, jenis kelamin, ras dan etnisitas. Tim adalah fitur yang paling penting dalam STAD. Pada tiap poinnya, yang ditekankan adalah membuat anggota tim melakukan yang terbaik untuk tim, dan tim pun harus melakukan yang terbaik untuk membantu tiap anggotanya. 3). Kuis, Setelah sekitar satu atau dua periode setelah guru memberikan presentasi dan sekitar satu atau dua periode praktik tim, para siswa akan mengerjakan kuis individual. Para siswa tidak diperbolehkan untuk saling membantu dalam mengerjakan kuis sehingga setiap siswa bertanggung jawab secara individual untuk memahami materinya. 4). Skor kemajuan individual, Gagasan di balik skor kemajuan individual adalah untuk memberikan kepada tiap siswa tujuan kinerja yang akan dapat dicapai apabila mereka bekerja lebih giat dan memberikan kinerja yang lebih baik daripada sebelumnya. 5). Rekognisi tim, tim akan mendapatkan sertifikat atau bentuk penghargaan yang lain apabila skor ratarata mereka mencapai kriteria tertentu. 
Skor tim siswa dapat juga digunakan untuk menentukan dua puluh persen dari peringkat mereka.

Menurut Borich, (2000: 389), suatu kegiatan pembelajaran kooperatif hampir sama dengan STAD adalah Teams Games Tournament (TGT). TGT menggunakan format umum sama seperti STAD (4 sampai 5 anggota kelompok belajar setiap lembar kerja). Namun, dari pada diberikan kuis individu dalam satu periode pembahasan, murid memainkan permainan akademis untuk memperlihatkan penguasaan dari topik yang mereka pelajari.

Wina Sanjaya (2011: 255) mengemukakan bahwa, "Pendekatan Kontekstual adalah suatu pendekatan pembelajaran yang menekankan kepada proses keterlibatan peserta didik secara penuh untuk dapat menemukan materi yang dipelajari dan menghubungkannya dengan situasi kehidupan nyata sehingga mendorong peserta didik untuk dapat menerapkannya dalam kehidupan mereka”.

$$
\text { Jonnasen (2011: }
$$

mendefinisikan kognitif sebagai konsep (skema), yaitu dasar dari pemahaman dan pemikiran manusia. Kotegori konsep adalah proses kognitif yang meresap dalam kehidupan sehari-hari karena kita memasuki masa untuk mendiskripsikan apa yang kita pikirkan atau menafsirkan apa yang orang lain katakan kepada kita.
Clikeman (2007:

memberikan pengertian tentang kemampuan sosial adalah suatu kemampuan untuk mengambil perspektif lain dengan memperhatikan suatu situasi dan untuk belajar dari pengalaman yang lalu dan menerapkan bahwa belajar adalah untuk perubahan sosial yang teratur. Kemampuan untuk merespon secara fleksibel dan secara tepat menegaskan kemampuan seseorang untuk memegang tantangan sosial yang diberikan.

\section{Metode Penelitian}

$\begin{array}{ccc}\text { Jenis } & \text { penelitian ini } & \text { adalah } \\ \text { penelitian } & \text { kuantitatif } & \text { dengan }\end{array}$
menggunakan metode eksperimen semu (quasi eksperimen) yang bertujuan untuk membandingkan dua kelompok eksperimen dengan kelompok kontrol, serta membandingkan antara dua kelompok eksperimen. Desain penelitian ini dipilih karena peneliti tidak melakukan random assignment, melainkan menggunakan kelompokkelompok yang ada sebagai kelompok eksperimen dan kelompok kontrol.

Populasi dalam penelitian ini adalah seluruh siswa kelas VII MTs Mu'allimin Muhammadiyah Yogyakarta, Jalan Letjen S. Parman 68 Yogyakarta, Tahun Pelajaran 2015/2016. Pengambilan sampel dilakukan dengan cara acak. Peneliti mengambil tiga kelas dari tujuh kelas VII. Kemudian peneliti akan memberi perlakuan dengan menggunakan 
model pembelajaran kooperatif tipe STAD dan TGT dengan pendekatan kontekstual pada masing-masing kelas eksperimen, serta pembelajaran konvensional pada kelas kontrol.

Teknik pengumpulan data pada penelitian ini adalah dengan pre-test dan post-test untuk mengukur kemampuan kognitif siswa, serta memberikan angket untuk mengukur kemampuan sosial siswa. Dengan instrumen pengumpulan data adalah instrumen tes berupa soal tes awal dan akhir, serta instrumen non tes berupa angket kemampuan sosial.

Teknik analisis data yang digunakan adalah 1). Analisis Deskriptif, data yang dideskripsikan merupakan data yang diperoleh dari pengukuran pada variabel-variabel penelitian (variabel terikat) yaitu kemampauan kognitif, dan sosial siswa. Data yang telah diperoleh dihitung nilai rata-ratanya kemudian diinterpretasi ke dalam kriteria-kriteria yang telah ditetapkan dan ditentukan persentasenya. 2). Analisis Statistik Inferensial, yaitu dengan statistik one sample t-test dengan bantuan SPSS 16.0.
Analisis ini dilakukan untuk mengetahui efektif tidaknya pembelajaran kooperatif tipe $S T A D$ dan $T G T$ dengan pendekatan kontekstual, serta pembelajaran konvensional pada masing-masing variabel kemampuan kognitif, dan sosial siswa. Data yang dianalisis dengan one sample t-test adalah data yang diperoleh dari hasil post-test serta angket kemampuan sosial setelah treatment.

\section{Hasil dan Pembahasan}

Data hasil tes kemampuan kognitif yang akan dideskripsikan terdiri atas data pre-test dan post-test yang disajikan pada tabel 1. Pre-test merupakan tes yang diberikan pada ketiga kelompok penelitian sebelum diberikan treatment. Tes ini bertujuan untuk mengetahui kemampuan awal siswa pada materi yang dieksperimenkan dan untuk melihat kesamaan sampel pada setiap kelas yang diteliti. Post-test dilaksanakan setelah treatment yang bertujuan untuk mengetahui kemampuan kognitif siswa setelah diberikan treatment.

Tabel 1. Deskripsi data hasil pre-test dan post-test

\begin{tabular}{lrrrrrr}
\hline \multirow{2}{*}{ Keterangan } & \multicolumn{2}{c}{ STAD \& Kontekstual } & \multicolumn{2}{c}{ TGT \& Kontekstual } & \multicolumn{2}{c}{ Kelas Kontrol } \\
\cline { 2 - 7 } Rata-rata & \multicolumn{1}{c}{ Pre-test } & Post-test & Pre-test & Post-test & Pre-test & \multicolumn{1}{c}{ Post-test } \\
Standar Deviasi & 65,82 & 72,64 & 67,16 & 73,18 & 66,74 & 74,62 \\
Varians & 9,86 & 12,48 & 8,16 & 12,26 & 6,86 & 10,75 \\
Nilai Ideal & 98,32 & 178,02 & 64,58 & 173,04 & 46,12 & 130,14 \\
Ketuntasan & 71,00 & 71,00 & 71,00 & 71,00 & 71,00 & 71,00 \\
\hline
\end{tabular}


Hasil analisis statistik deskriptif yang tersaji pada tabel 1. menunjukkan bahwa rata-rata nilai pre-test pada kelas STAD dengan pendekatan kontekstual sebesar 65,82; kelas TGT dengan pendekatan kontekstual sebesar 67,16 dan kelas kontrol 66,74. Rata-rata nilai posttest pada kelas STAD, TGT dengan pendekatan kontekstual, dan kontrol masing-masing adalah 72,$64 ; 73,18$; dan 74,62. Pada saat pre-test tidak ada siswa yang tuntas untuk ketiga kelas, atau dapat dikatakan ketuntasan 0,00 \% pada semua kelas yang diteliti. Setelah treatment, terjadi peningkatan kemampuan kognitif siswa ditunjukkan dengan adanya peningkatan ketuntasan dari pre-test dan post-test pada kelas STAD, TGT dengan pendekatan kontekstual, dan kontrol masing-masing adalah 58,86 \%; 62,68\%; dan $42,28 \%$.

Sebelum dan setelah diberikan treatment, dilakukan perngukuran pada kelas eksperimen dan kelas kontrol untuk memperoleh data kemampuan sosial siswa dalam pembelajaran matematika. Data tersebut disajikan pada tabel 2 . berikut:

Tabel 2. Deskripsi data pengukuran kemampuan sosial siswa sebelum dan setelah treatment

\begin{tabular}{lrrrrrr}
\hline \multirow{2}{*}{ Keterangan } & \multicolumn{2}{c}{ STAD \& Konntekstual } & \multicolumn{2}{c}{ TGT \& Kontekstual } & \multicolumn{2}{c}{ Kelas Kontrol } \\
\cline { 2 - 7 } & \multicolumn{1}{c}{ Sebelum } & Setelah & \multicolumn{1}{c}{ Sebelum } & \multicolumn{1}{c}{ Setelah } & \multicolumn{1}{c}{ Sebelum } & \multicolumn{1}{c}{ Setelah } \\
Rata-rata & 87.88 & 100.64 & 88.78 & 96.46 & 88.76 & 88.36 \\
Standar Deviasi & 10.86 & 11.76 & 11.46 & 10.68 & 10.92 & 11.22 \\
Varians & 122.40 & 130.88 & 125.96 & 112.48 & 116.82 & 128.94 \\
Nilai Ideal & 93 & 93 & 93 & 93 & 93 & 93 \\
\hline
\end{tabular}

Berdasarkan hasil analisis statistik deskriptif yang disajikan pada tabel 2, hasil pengukuran menunjukkan bahwa rata-rata hasil pengukuran kemampuan sosial siswas ebelum treatment pada kelas STAD dengan pendekatan kontekstual adalah 87,88; pada kelas $T G T$ dengan pendekatan kontekstual 88,78; dan kelas kontrol 88,76. Kemampuan sosial siswa setelah treatment pada kelas STAD dengan pendekatan kontekstual menunjukkan angka 100,64; pada kelas
$T G T$ dengan pendekatan kontekstual 96,46; dan pada kelas kontrol 88,36.

Frekuensi dan persentase banyak siswa pada setiap kriteria kemampuan sosial siswa dihitung sebagaimana rentang skor yang telah ditentukan. Kemampuan sosial awal dari 38 siswa pada kelas STAD dengan pendekatan kontekstual, tidak ada siswa $(0 \%)$ yang memiliki kemampuan sosial sangat kurang baik dan kurang baik, 24 siswa $(63,16 \%)$ yang memiliki kemampuan sosial cukup baik, 5 siswa $(13,16 \%)$ yang memiliki kemampuan sosial baik, 
dan 9 siswa $(23,68 \%)$ yang memiliki kemampuan sosial sangat baik. Dengan demikian, sebagian besar siswa pada kelas STAD dengan pendekatan kontekstual sebelum treatment memiliki kemampuan sosial cukup baik.

Kemampuan sosial dari 36 siswa pada kelas $T G T$ dengan pendekatan kontekstual, tidak ada siswa (0\%) yang memiliki kemampuan sosial sangat kurang baik dan kurang baik, 24 siswa $(66,67 \%)$ yang memiliki kemampuan sosial cukup baik, 6 siswa $(16,67 \%)$ yang memiliki kemampuan sosial baik, dan 6 siswa $(16,67 \%)$ yang memiliki kemampuan sosial sangat baik. Sebagian besar siswa pada kelas TGT dengan pendekatan kontekstual sebelum treatment memiliki kemampuan sosial cukup baik.

Kemampuan sosial awal dari 35 siswa pada kelas kontrol sebagian besar memenuhi kriteria cukup baik, yaitu sebanyak 20 siswa $(57,14 \%)$ mendapat rentang nilai antara 69 sampai 95. Terdapat 2 siswa memenuhi kriteria kurang baik, 7 siswa (20\%) baik, dan 6 siswa $(17,14 \%)$ sangat baik.

Perolehan skor untuk kemampuan sosial siswa setelah diadakan treatment menunjukkan, dari 38 siswa pada kelas STAD dengan pendekatan kontekstual, tidak ada siswa (0 \%) yang memiliki kemampuan sosial sangat kurang baik dan kurang baik, 12 siswa $(31,58 \%)$ yang memiliki kemampuan sosial cukup baik, 6 siswa $(15,79 \%)$ yang memiliki kemampuan sosial baik, dan 20 siswa $(52,63 \%)$ yang memiliki kemampuan sosial sangat baik,. Dengan demikian, sebagian besar siswa pada kelas STAD dengan pendekatan kontekstual setelah treatment memiliki kemampuan sosial sangat baik.

Data dari 36 siswa pada kelas TGT dengan pendekatan kontekstual mengenai kemampuan sosial siswa menunjukkan tidak ada siswa (0\%) yang memenuhi kriteria sangat kurang baik dan kurang baik, 15 siswa (41,67 \%) pada criteria cukup baik, 5 siswa $(13,39 \%)$ pada kriteria baik, dan 16 siswa $(44,44$ $\%$ ) yang memiliki kemampuan sosial sangat baik. Dengan demikian, sebagian besar siswa pada kelas TGT dengan pendekatan kontekstual setelah treatment memiliki kemampuan sosial sangat baik.

Kemampuan sosial setelah treatment dari 35 siswa pada kelas kontrol sebagian besar memenuhi kriteria cukup baik, yaitu sebanyak 22 siswa $(62,86 \%)$ mendapat rentang nilai antara 70 sampai 95 . Terdapat 4 siswa $(11,43$ \%) memenuhi kriteria baik, dan 9 siswa $(25,71 \%)$ sangat baik.

Keefektifan model pembelajaran kooperatif tipe STAD dan Teams TGT dengan pendekatan kontekstual serta pembelajaran konvensional ditinjau dari kemampuan kognitif, dan sosial siswa Keefektifan setiap model dan metode pembelajaran kooperatif ditinjau 
dari kemampuan kognitif, dan sosial siswa kelas VII MTs Mu'allimin Muhammadiyah Yogyakarta, dapat dilihat dari kriteria ketuntasan minimal (KKM) yang telah ditentukan untuk masing-masing variabel dependen. KKM yang telah ditentukan untuk kemampuan kognitif adalah KKM yang telah ditentukan sekolah yaitu 71. Sedangkan untuk kemampuan sosial siswa dikatakan berhasil apabila mendapat jumlah skor minimal 93.

Penerapan model pembelajaran kooperatif pada kelompok eksperimen pertama, berdasarkan kriteria keputusan pada t-test one sample, pembelajaran kooperatif tipe $S T A D$ dengan pendekatan kontekstual efektif ditinjau dari kemampuan kognitif dan kemampuan sosial siswa. Hal ini disebabkan karena dalam proses pembelajaran matematika siswa berpartisipasi aktif melalui diskusi dengan anggota-anggota kelompoknya. Adanya kuis pada setiap akhir pembelajaran yang dihitung berdasarkan kemajuan kelompok secara tidak langsung memberikan tanggung jawab kepada siswa untuk keberhasilan kelompok masing-masing. Rekognisi atau penghargaan kelompok juga membuat senang dan terpacu untuk belajar, serta menjadi lebih baik dari sebelumnya.

Penerapan model pembelajaran kooperatif pada kelompok eksperimen kedua, guru menerapkan pembelajaran kooperatif tipe $T G T$ dengan pendekatan kontekstual. Berdasarkan kriteria keputusan pada t-test one sample, pembelajaran kooperatif tipe $T G T$ dengan pendekatan kontekstual efektif ditinjau dari kemampuan kognitif dan kemampuan sosial siswa. Seperti halnya pada $S T A D$, dalam proses pembelajaran matematika siswa berpartisipasi aktif melalui diskusi dengan anggota-anggota kelompoknya. Turnamen akademik pada setiap akhir pembelajaran memacu kemampuan siswa untuk berkompetisi menjawab pertanyaan-pertanyaan yang berkaitan dengan materi. Siswa diberikan penghargaan sehingga siswa menjadi senang dan terpacu untuk belajar, dan menjadi lebih baik dari sebelumnya.

Berdasarkan kriteria keputusan pada t-test one sample, Pembelajaran dengan metode konvensional tidak efektif ditinjau dari kemampuan kognitif, dan sosial siswa. Beberapa hal yang menyebabkan metode ini tidak efektif antara lain: 1) proses pemberian informasi hanya berlangsung dua arah, yaitu dari guru ke siswa sehingga siswa tidak terpacu untuk menemukan sendiri informasi yang terkait dengan materi; 2) tanggung jawab hanya untuk diri siswa sendiri sehingga kurang ada upaya untuk optimalisasi diri; 3) tidak adanya diskusi untuk menyelesaikan masalah bersama sehingga sosialisasi siswa kurang.

$$
\text { Dengan demikian dapat }
$$
disimpulkan bahwa kedua model 
pembelajaran baik pembelajaran kooperatif tipe $S T A D$ dan $T G T$ dengan pendekatan kontekstual efektif ditinjau dari kemampuan sosial siswa tetapi tidak efektif ditinjau dari kemampuan kognitif siswa. Adapun pembelajaran dengan metode konvensional ternyata kurang efektif ditinjau dari kemampuan kognitif, dan sosial siswa.

Komparasi pengaruh model pembelajaran kooperatif tipe STAD dan TGT dengan pendekatan kontekstual dengan pembelajaran konvensional ditinjau dari kemampuan kognitif, dan sosial siswa

Berdasarkan hasil analisis secara multivariate untuk melihat perbedaan antara kelas kontrol dengan kelas eksperimen, diperoleh nilai $p$ value untuk setiap uji statistik sebesar 0,001 . Hal ini menunjukkan bahwa nilai $p$ value lebih kecil dari taraf signifikansi yang digunakan yaitu 5\%. Dengan demikian, berarti hipotesis nol penelitian yang berbunyi "Tidak terdapat perbedaan pengaruh pembelajaran konvensional dan model pembelajaran kooperatif terhadap kemampuan kognitif, dan sosial siswa" ditolak. Hal itu menunjukkan terdapat perbedaan pengaruh atau tingkat keefektifan antara pembelajaran konvensional dan model pembelajaran kooperatif. Setelah diketahui kedua model pembelajaran memiliki pengaruh yang berbeda secara simultan, kemudian dilakukan uji lanjut secara univariat Keefektifan ... (Roestin Puput Anggoro) untuk mengetahui model pembelajaran mana yang lebih unggul untuk setiap variabel.

Hasil uji lanjut menunjukkan bahwa pada aspek kemampuan kognitif, $S T A D$ dan $T G T$ dengan pendekatan kontekstual lebih baik daripada pembelajaran konvensional. Pada aspek kemampuan sosial siswa, STAD dan TGT dengan pendekatan kontekstual juga lebih baik dari pada pembelajaran konvensional. Dengan demikian, berarti model pembelajaran kooperatif tipe STAD dan TGT dengan pendekatan kontekstual adalah model pembelajaran yang lebih efektif.

Komparasi pengaruh model pembelajaran kooperatif tipe STAD dan TGT dengan pendekatan kontekstual ditinjau dari kemampuan kognitif, dan sosial siswa

Berdasarkan hasil analisis secara multivariate untuk melihat perbedaan antara kelas kontrol dengan kelas eksperimen, diperoleh nilai $p$ value untuk setiap uji statistik sebesar 0,214 . Hal ini menunjukkan bahwa nilai $p$ value lebih besar dari taraf signifikansi yang digunakan yaitu 5\%. Dengan demikian, berarti hipotesis nol penelitian yang berbunyi "Tidak terdapat perbedaan pengaruh model pembelajaran kooperatif tipe $S T A D$ dan $T G T$ dengan pendekatan kontekstual terhadap kemampuan kognitif, dan sosial siswa" diterima. Hal ini menunjukkan tidak terdapat 
perbedaan pengaruh atau tingkat keefektifan antara pembelajaran model pembelajaran kooperatif tipe $S T A D$ dan TGT. Setelah diketahui kedua model pembelajaran memiliki pengaruh yang tidak berbeda secara simultan, maka tidak perlu dilakukan uji lanjut secara univariat.

Hasil analisis yang diperoleh yakni "Tidak terdapat perbedaan pengaruh model pembelajaran kooperatif tipe $S T A D$ dan $T G T$ dengan pendekatan kontekstual terhadap kemampuan kognitif, mental, dan sosial siswa" tidak sesuai dengan hipotesis penelitian yang telah dirumuskan. Hal ini disebabkan antara lain karena: 1). Pada pelaksanaan model pembelajaran kooperatif tipe $T G T$ dengan pendekatan kontekstual, tujuan turnamen akademik belum tercapai secara maksimal. Turnamen akademik dimaksudkan untuk merangsang sikap kompetitif siswa dengan berlomba-lomba menjawab soal turnamen dengan benar. Namun pada kenyataanya, beberapa siswa menganggap turnamen akademik hanya sekadar permainan belaka. 2). Pada kelas TGT dengan pendekatan kontekstual, beberapa siswa mengeluh dan merasa tidak sesuai dengan teman satu kelompoknya sehingga pelaksanaan diskusi kelompok kurang maksimal. 3). Pelaksanaan pembelajaran kooperatif khususnya tipe TGT dengan pendekatan kontekstual tidak maksimal karena tidak didukung secara optimal dengan kesiapan siswa (siswa masih belum terbiasa dengan pembelajaran kooperatif) dalam pembelajaran matematika.

Walaupun tidak terdapat perbedaan pengaruh antara model pembelajaran kooperatif tipe $S T A D$ dan TGT dengan pendekatan kontekstual, keduanya memiliki pengaruh yang signifikan terhadap kemampuan kognitif, dan sosial siswa dalam pembelajaran matematika khususnya pada materi pokok garis dan sudut. Dengan demikian, baik STAD maupun TGT dengan pendekatan kontekstual sebagai tipe pada model pembelajaran kooperatif, keduanya mampu meningkatkan kemampuan kognitif, dan sosial siswa.

\section{Kesimpulan dan Saran}

Berdasarkan hasil analisis data dan pembahasan, maka dapat disimpulkan beberapa hal sebagai berikut: 1). Model pembelajaran kooperatif tipe STAD dan TGT dengan pendekatan kontekstual efektif ditinjau dari kemampuan kognitif dan kemampuan sosial siswa, sedangkan pembelajaran konvensional tidak efektif ditinjau dari kemampuan kognitif, dan sosial siswa. 2). Terdapat perbedaan yang signifikan mengenai pengaruh model pembelajaran kooperatif tipe STAD dan $T G T$ dengan pendekatan kontekstual dengan pembelajaran konvensional ditinjau dari kemampuan kognitif, dan sosial siswa. 3) Tidak terdapat perbedaan yang signifikan mengenai pengaruh 
model pembelajaran kooperatif tipe STAD dengan pendekatan kontekstual dan model pembelajaran kooperatif tipe TGT dengan pendekatan kontekstual ditinjau dari kemampuan kognitif, dan sosial siswa. 4). Model pembelajaran kooperatif tipe $S T A D$ dengan pendekatan kontekstual lebih baik dari pada pembelajaran konvensional pada aspek kemampuan sosial, sedangkan model pembelajaran kooperatiftipe $T G T$ dengan pendekatan kontekstual lebih baik dari pada pembelajaran konvensional pada aspek kemampuan kognitif, dan sosial siswa.

Berdasarkan hasil dan temuan yang diperoleh di atas, ada beberapa saran yang dapat disampaikan adalah: 1). Disarankan pada guru untuk menerapkan berbagai model dan pendekatan pembelajaran yang memungkinkan siswa untuk berpartisipasi aktif dalam belajar atau berpusat pada siswa. 2). Disarankan kepada pengajar matematika untuk menerapkan model pembelajaran kooperatif tipe $S T A D$ dan $T G T$ dengan pendekatan kontekstual serta memberikan penghargaan yang motivatif dalam pembelajaran matematika, sehingga membawa dampak yang positif pada peningkatan kemampuan kognitif, dan sosial siswa. 3). Dalam menerapkan model pembelajaran kooperatif tipe STAD dan TGT dengan pendekatan arta: Kencana Media Group. kontekstual, hendaknya menyiapkan segala perangkat pembelajaran yang dibutuhkan, terutama LKS untuk mengaktifkan kegiatan belajar siswa. 4). Disarankan kepada peneliti agar memperluas materi yang digunakan dalam penelitian, sehingga memungkinkan generalisasi yang lebih luas.

\section{Pustaka}

Arends, R. I., \& Kilcher, A. (2010). Teaching for student learning: Becoming an accumplhised teacher. New York: Taylor \& Francis e- Library.

Borich, G. D. (2000). Efective Teaching Methods. Columbus, Ohio: Merilan Imprint of Prentice Hall.

Clikeman, M. S. (2007). Social Competence in Children. New York: Springer

Science+Business Media.

Jonnasen, D. H. (2011). Learning to Solve Problems: A Handbook for Designing Problem-Solving Learning Environments. New York: Routledge

Slavin, R. E. (2005). Cooperative Learning: theory, research and practice. London: Allymand Bacon.

Wina Sanjaya. (2011). Strategi pembelajaran berorientasi standar proses pendidikan. Jak 